Social Sciences: Achievements and Prospects Journal 3(11), 2019

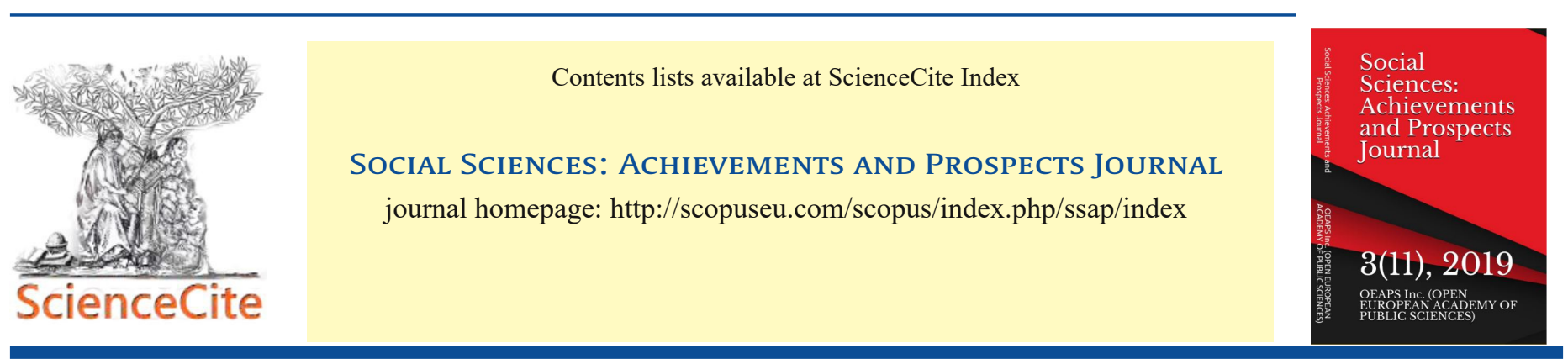

\title{
TRADE RELATIONS BETWEEN BUKHARA AND RUSSIA IN THE SECOND HALF OF THE XIX CENTURY - THE BEGINNING OF THE XX CENTURY
}

\section{Fayzulla Ochildiyev}

Candidate of historical sciences, Senior Lecturer, head of the department of archeology and ethnology, Faculty of History, National University of Uzbekistan, Tashkent, Uzbekistan

\begin{tabular}{|c|c|}
\hline ARTICLE INFO & ABSTRACT \\
\hline $\begin{array}{ll}\text { Article history: } & \\
\text { Received } & \text { Feb/28/2019 } \\
\text { Accepted } & \text { Mar/10/2019 } \\
\text { Available online } & \text { Mar/16/2019 } \\
\text { Keywords: } & \end{array}$ & $\begin{array}{l}\text { This article discusses the history of trade relations between the } \\
\text { Bukhara emirate and Russia in the second half of the 19th and early } \\
\text { 20th centuries, as well as products exported from Bukhara to Russia, } \\
\text { the development of trade relations between the two countries over the } \\
\text { years. The trade relations of the Bukhara merchants with Orenburg, } \\
\text { Orsk, Tyumen, Astrakhan, Moscow, St. Petersburg, Kazan and other } \\
\text { cities were studied. Studies of the Russian empire in Central Asia, } \\
\text { extensive military and political actions against the khanates, the } \\
\text { creation of a Russian political agency in Bukhara, railway access to } \\
\text { Bukhara and cotton cultivation in the country by the Russian } \\
\text { government, pursuing their own interests, were discussed. } \\
\text { development industry. }\end{array}$ \\
\hline
\end{tabular}

(c) 2019 The Author. Published by OEAPS Inc. This is an open access article under the CC BY-NC-ND license (http://creativecommons.org/licenses/by-nc-nd/4.0/).

\footnotetext{
* Corresponding author. E-mail address:

radjabov_1994@inbox.ru
}

Crossref DOI:

EU Sciences Cataloge DOI: 10.5281/zenodo.2614356 
Russia occupied a leading place in trade relations with foreign countries of the Bukhara Khanate. In Bukhara, there was a great need for goods imported from Russia. Products exported from Bukhara to Russia also, in turn, were in demand in the Russian markets. For this reason, trade relations between the two countries have evolved over the years. Bukhara merchants are active in trading in the Russian cities of Orenburg, Orsk, Tyumen, Astrakhan, Moscow, St. Petersburg, Kazan and other cities(1).

In the second half of the XIX century in Russia there were serious economic changes. As a result of a certain development of the industrial sector, problems began in the country to sell products in foreign markets. In addressing these problems, Central Asia was chosen as one of the main sales markets.

In 1852, the governor of Orenburg, Kryyanovsky, wrote to the Russian government: "We cannot promote and expand Russian trade in Central Asia (the khanates) if we do not obey this region and do not achieve recognition of our will as laws for the edges".

The Russian Empire began to prepare for large-scale military-political actions against the Khanate, pursuing its own interests, in connection with economic problems and in order to develop industry. In 1858, a mission led by $\mathrm{N}$. Ignatiev visited the Khiva and Bukhara khanates. Although Ignatiev's actions failed in the Khiva Khanate, some positive results were achieved in Bukhara. The emir of Bukhara agreed to the requirements proposed by Ignatiev. The requirements for the Bukhara government included the following: reduction of duties on Russian goods, the introduction of a temporary trade agency in Bukhara, the release of Russian prisoners held in captivity, and the allocation of a separate caravanserai for Russian merchants(2).

According to the information provided by Turkestan
Gazette, the emir of Bukhara did not fulfill the terms of the agreement established by Ignatiev, and that the issues were not resolved(3).

As a result of the Russian occupation of Central Asia, the commodity turnover between the Bukhara Emirate and Russia decreased. If from Bukhara to Russia in 1864, goods were sold for 6,868.343 soums, in 1865 it fell to $3,454.319$ soums. During this period, trade from Russia to Bukhara decreased from $4,654,988$ soums to $2,250,853$ soums(4).

The sale of goods from Bukhara to Russia began to accelerate again from 1867 . It should be noted that even after the occupation of Tashkent by the Russian Empire, Bukhara maintained its leading position in the export of cotton and yarn in Central Asia. In 1867 the cost of goods from Tashkent to Russia amounted to 868 thousand soums, from Khiva to Russia - 1 million 421 thousand soums, in from from Bukhara to Russia - 6 million 215 thousand soums. According to the data, Bukhara had intensive trade relations with Russia during this period(5).

In accordance with the agreement signed on June 23, 1868 between Russia and the Emirate of Bukhara, the territories from Khujand, Uratepa, Jizzak, Samarkand and Kattakurgan to Zirabulak were transferred to Russia. The agreement also provided for free trade and the safety of Russian citizens in all regions of the Bukhara Emirate, the right to open trading agencies by Russian merchants, factories where they want, setting a duty of $2.5 \%$ of the goods of Russian merchants, free promotion to neighboring states through the territory Bukhara Emirate.

On September 18, 1873, a new agreement between Russia and Bukhara was signed in Shakhrisabz, according to which Bukhara was considered a vassal of Russia, and it was forbidden to conduct independent diplomatic relations with foreign countries. This agreement created a number of 
advantages for Russian merchants. One of the privileges granted to them was the right of duty-free movement from the territory of the Bukhara Emirate to other countries(6).

After Russia's conquest of Central Asia, the Turkestan General Government was created. This prompted the Russian government to pursue a policy of influence on the Bukhara economy as quickly as possible. As a result of the introduction of the formation of the Governor-General of Turkestan, the customs posts in Petropavlovsk, Semipalatinsk, Orenburg and Troitsk lost their former importance. During this period, duties on goods from Bukhara merchants to Russia were abolished, but there were cases when customs inspectors, along with other merchants, imposed duties. This led to the discontent of the Bukhara merchants. As a result, the Russian government closed the Orenburg-Siberian customs post on April 22, 1868(7).

Due to the civil war in the United States, the influx of cotton and other industrial goods to Russia has sharply declined. Now the Russian government sets the task to export the raw materials needed for the textile industry from the khanates of Central Asia and develop cotton growing. On the initiative of Kaufman on December 12, 1868, a decree was signed that Russian industry supplied the raw materials needed for this industry from Central Asia. The decree introduced a ban on the collection of duties from Central Asian countries transporting raw materials for Russian industry(8).

It also led to the development of trade relations between Bukhara and Russia in some respects. Another feature of the Kaufman decree was that the share of local craftsmanship from the Bukhara Emirate to Russia dropped sharply. Significantly increased the prestige of the industry, such as cotton, silk and astrakhan. 1 pound of cotton from Bukhara at the Nizhny Novgorod fair was sold in 1861 for 7 sums 50 penny(tiyin), in 1862 - 12-13 sums, and in 1864 - 22-23 sums in 1864(9).

Due to the fact that cotton prices on the Russian market increased, the Bukhara merchants benefited from the cotton trade. Local merchants (in 1869) bought each pood of cotton in the Bukhara markets for 4-4.5 soums(10), sold at the Nizhny Novgorod fair for 15 soums(11). Cotton fiber in Bukhara was much lower than American cotton. But it was cheaper than American cotton from the Liverpool stock market. Also, Bukhara cotton products were affordable and cheap for Russians.

From the 1870s, imports of Russian industrial products to Bukhara began to increase. Fabrics, jute, furs, copper, tin, lead, iron utensils, sugar, paper, mercury, Ufa leather, kenaf of Yaroslavl, silk threads, pearls and various dyes began to be delivered to the Emirate of Bukhara(12).

From Bukhara (1870) to Russia, except for cotton, silk and karakul peel, goods were exported: dried fruits, apricots, peaches, plums, nuts, almonds, raisins, dried melons, medicinal herbs, spinach, indigo for paint(13).

In the 80 s of the 19th century, trade with Bukhara became more lively with Russia. British goods on the Bukhara markets were sold much cheaper compared to Russian goods. Therefore, the Russian government began to take measures to oust British goods from the Bukhara markets(14). From 1880 to $1881,4,000$ pounds of karakul and other leathers, 140 thousand pounds of cotton, 4,800 pounds of kenaf and 100 pounds of medicinal seeds were exported from Russia to the Bukhara Emirate. From Bukhara to Russia - 7 thousand pounds of sugar, 2 thousand pounds of livestock products, 2300 pounds of iron products and 43 pounds of goods of the manufactory(15). 
According to the data, despite the fact that Russian goods were widely sold in the Bukhara markets, the position of Russian merchants in the commodity markets was unstable. Bukhara merchants, without the participation of Russian merchants, independently brought goods from Nizhny Novgorod, Moscow, Orenburg and other cities(15). After 1880, Russian merchants began to dominate Russian-Bukhara trade affairs. A number of trading societies and warehouses were established in Bukhara. One of these societies is the Russian logistics company in Bukhara. In 1883, 13.504 tons of cotton, 1,200 tons of silk, 304 tons of astrakhan, 260 tons of sarnak and 800 tons of other products were exported from Bukhara to Russia(16).

The creation of a Russian political agency in Bukhara (1885) and the introduction of posts for special assignments in the Finance Ministry of Russia in Tashkent created an excellent opportunity for Russian merchants to actively enter the markets of the Bukhara Emirate. The political agency directly controlled the activities of the Bukhara government and defended the interests of Russian traders and citizens in the Bukhara Emirate. At the same time, Russian merchants sponsored them in the sale and purchase of goods.

In order to further enhance the political and economic status of the Russian government in Bukhara since 1886, the Ministry of Finance became responsible for controlling trade between Russia and Bukhara. At the same time, the ministry was tasked with examining the needs of local trade in Turkestan and Bukhara and further improving customs control activities(17).

In 1887, in Bukhara, the production agency of the Russian firms and trading agencies N. Kudrin, Dyurshmidt, Dukov, Devlekhimov, Ibragimov brothers, Adamov and Daminov established their trading activities. In addition, the Russian Society, the Caucasus and Mercury, Nadezhda, Kudrin comradely society, began to operate, which carry out insurance and transportation of goods. Bukhara societies began to benefit from the delivery of Bukhara goods to Russian industrial centers. Only the company Yaroslavl manufactory bought 100 thousand pounds of cotton in Bukhara in 1884, and in 1889 the amount of cotton they purchased amounted to 240 thousand pounds(18).

If Bukhara merchants occupied a high position in trade, then in the second half of the 80 s there was equality of forces in bilateral trade, then Russian merchants gained dominance on this side thanks to extensive Russian investments and the construction of railways in Chardzhou and Bukhara.

In connection with the construction of railways in Chardzhou and Bukhara, Russian businessmen, not buying raw materials from Bukhara at fairs, began to receive directly. Previously, each pood of goods was transported to Russia via caravan routes for 3 soums, now the cost was a total of 70 pennys, including insurance(19).

When comparing the trade relations of BukharaRussia of the 1880s and 1890s, it is determined that Bukhara during this period was more involved in Russian domestic markets. According to I.A. Remeza, in 1880-1881, 410 thousand poods of cotton were sent from Bukhara to Russia. In 1890, after the construction of the railway, this figure was 1 mil. 360 thousand pounds. In addition, during this period, the supply of astrakhan and other various hides varied from 4,000 pounds to 50,000 pounds. As a result of the expansion of cotton fields in the emirate, these products were imported from Russia to meet the needs of the population of the emirate in wheat, flour and rice. Until the early 1880 s, the emirate was fully self-sufficient in grain. And in 1890, 660 thousand pounds of wheat and flour and 650 thousand pounds of rice were imported into the Bukhara emirate from Russia.

Since the 1890s, Russian factories produced shirts, 
fine linen, silk and semi-silk fabrics, Asian shoes, lamps, glassware, copper, copperware, chests and confectionery for sale in the markets of Bukhara and other khanates of the Middle Asia Representatives of Moscow and other firms are beginning to exchange the above listed goods for raw materials from local residents(20).

As a result, there have been some changes in the trade between Russia and Bukhara. For example, the export of handicraft products from Bukhara to Russia declined sharply(21). As a result, the Bukhara artisans went bankrupt. In 1880-1881 4.800 pounds of kenaf were delivered from Bukhara to Russia, but in 1890, on the contrary, 10 thousand pounds of kenaf were exported from Russia to Bukhara, and in 1891 27 thousand pounds of kenaf. As a result of the measures taken by the Russian government to grow cotton in the country, in 1884 they began to sow American cotton in Central Asia(22).

This event also did not set aside the Bukhara emirate. This policy has not banned completely sowing local cotton. Although the local cotton of the Bukhara emirate was worse than the American variety, but nevertheless it required less water and fertilizer, it was frost-resistant. As a result of these advantages, local varieties of cotton planting cotton in the emirate persists for a long time.

By 1893, Chorji, a Central Asian commercial and industrial firm, began distributing seeds to farmers free of charge when buying the harvest. Since then, in all the cotton markets in the Emirate, on the recommendation of Russian firms, special observers have been appointed so that they do not include poor quality cotton in the markets(23). According to the information, farmers who imported poor quality cotton to cotton fields in the Emirate were shot with darra from five to ten by order of local authorities(24).
In almost every village in the Emirates, there were markets for cotton, these cotton markets were rented by aminonians (taxpayers), and tenants distributed the balances to markets and were market owners. They were taxpayers during the cotton harvest, as well as intermediaries between cotton sellers and Russian purchasers. Cotton buyers traded in advance for buying cotton more than cotton, while the scales provided part of the advance to farmers, that is, farmers, or as collateral(25).

Since traders were rewarded, traders must pay scales of up to 5-7 pounds of cotton, sometimes up to 10 pounds, up to 6-7 pounds on the cotton market, and up to 1.5 pounds for each pouch. All markets in Bukhara are constantly monitored by markets to prevent poor cotton production(26). According to Mirbadalov, a major trader in Bukhara who examined the cotton markets in the markets in Bukhara in 1893, this year the Pirmast breeders in the Bukhara Emirate found that poor quality cotton was produced.

Bukhara from the Caspian highway increases domestic supplies of cotton (cotton) to Russian cotton processing centers. For example, Abdunabi - 60, Mullah Abdulwahab - 30, Kazakh - 15 cars sent to Moscow industrial plants every year. The station Bukhara (Kagan) was especially important for sending cotton to Russia between the railway stations in the Emirate(27).

Bukhara merchants who are engaged in the cotton trade have now begun to use railways. Gradually, caravan routes and caravans lost their meaning. The volume of freight increased, and the cost of freight was also significantly lower.

\section{References}

1. РожковаМ.К. Экономические связи России со Средней Азии 40-60-е годы XIX века. M.A.H.CCCP, - 1963. C.45. 
2.Игнатьев Н.П. Миссии в Хиву и Бухару в 1858 г., - Спб, 1897. С.227-228.

3.Туркестанские ведомости. № 5. 22 февраля. 1871 г.

4.Раззоқов Д.Х. Бохоро хонлигининг ташқи савдо алоқалари. т.ф.н. олиш учун ёзилган диссертация.T.1994. 53. б.

5.РожковаМ.К. Экономические связи России со Средней Азии 40-60-е годы XIX века. M.A.H.CCCP, - 1963. C.64.

6.ЎзРМДА. 3-жамғарма, 2-рўйхат, 1-иш, 2-варақ.

7.Туркестанские ведомости. № 5. 22 февраля. 1871 г.

8.Раззоқов Д.Х. Бохоро хонлигининг ташқи савдо алоқалари. т.ф.н. олиш учун ёзилган диссертация.T.1994. C.56.

9. Раззоқов Д.Х. Бохоро хонлигининг ташқи савдо алоқалари. т.ф.н. олиш учун ёзилган диссертация.Т.1994. 56. б.

10.Туркестанские сборник. Том. 8. - С.23.

11.Туркестанские сборник. Том. 26. - С.77.

12.Раззоқов Д.Х. Бохоро хонлигининг ташқи савдо алоқалари. т.ф.н. олиш учун ёзилган диссертация.-Т.1994. С.63.

13.Туркестанские сборник. Том. 29. - С.274.

14.Ремез И.А. Внешняя торговля Бухары до мировой войны. -Т. 1992. С.49.

15.Раззоқов Д.Х. Бохоро хонлигининг ташқи савдо алоқалари. т.ф.н. олиш учун ёзилган диссертация.-Т.1994. С.65

16.Сборник географических, топографических и статистических материалов по Азии. -СПб., 1885. Вып. ХУ. С. 185.

17. Раззоқов Д.Х. Бохоро хонлигининг ташқи савдо алоқалари. т.ф.н. олиш учун ёзилган диссертация.-Т.1994. 67. б.

18.Юлдашев А. Аграрные отношениях в Туркестане. Т. 1969. С. 107.

19.Губаревич-Родобльский А.Ф. Экономический очерк Бухары и Туниса. - СПб.1905. С. 91.

20.Ремез И.А. Внешняя торговля Бухары до мировой войны. -Т. 1992. - С. 49.
21.Раззоқов Д.Х. Бохоро хонлигининг ташқи савдо алоқалари. Т.ф.н. олиш учун ёзилган диссертация.-Т.1994. С. 73.

22. Раззоқов Д.Х. Бохоро хонлигининг ташқи савдо алоқалари. т.ф.н. олиш учун ёзилган диссертация.-Т.1994. 73. б.

23. ЎзРДА， 3-жамғарма， 3-рўйхат， 78-иш， 55варақ.

24.ЎзРМДА，1-жамғарма，11-рўйхат, 1372-иш, 3варақ орқаси.

25.ЎзРМДА, 1-жамғарма, 11-рўйхат, 1372-иш, 14варақ.

26. ЎзМДА, 1-жамғарма, 11-рўйхат, 1372-иш, 15варақ.

27.ЎзРМДА, И-3-жамғарма, 2c-рўйхат, 43c-иш, 1варақ. 